\title{
CLONING AND in silico STUDIES OF LIPASE GENE OF A THERMOPHILIC BACTERIA ISOLATED FROM THE HYDROTHERMAL VENT AREA OF KAWIO, NORTH SULAWESI
}

\author{
KHALILAN LAMBANGSARI ${ }^{1}$, MAELITA RAMDANI MOEIS ${ }^{1}$ and ELVI RESTIAWATY2,3* \\ ${ }^{1}$ School of Life Science and Technology, Institute of Technology Bandung, \\ Ganesha 10 Bandung 40132 \\ ${ }^{2}$ Research Group of Chemical Engineering Design and Development, \\ Faculty of Industrial Technology, Institute of Technology Bandung, \\ Ganesha 10 Bandung 40132 \\ ${ }^{3}$ Biosciences and Biotechnology Research Center, Institute of Technology Bandung, \\ Ganesha 10 Bandung 40132 \\ *E-mail: erestiawaty@che.itb.ac.id
}

Accepted 7 May 2020, Published online 6 July 2020

\begin{abstract}
Underwater volcano is an example of a natural habitat of thermophilic bacteria, such as hydrothermal vent Kawio in North Sulawesi. The focus of this research was to screen the bacterial isolates originally from hydrothermal vent Kawio for the production of thermostable lipase. In this study, the lipase gene from the selected isolate was cloned, sequenced, and in silico analysis was performed to predict the characteristics of the lipase protein. One of three isolates examined, showed a positive reaction. Phylogenetic analysis of $16 \mathrm{~S}$ rRNA gene showed that the isolate was a novel bacteria closely related to Bacillus safensis strain FO-26b with 96,87\% homology. Amino acid sequence analysis of the lipase showed similarity between lipase of Bacillus pumilus strain B106 with 98\% homology. Further analysis at the protein level indicated that the lipase isolated from marine water was a member of family I.4 of 'true lipase' group.
\end{abstract}

Key words: Lipase, thermophlic bacteria, hydrothermal vent, Bacillus safensis

\section{INTRODUCTION}

Lipases (triacylglycerol acylhydrolase, EC 3.1.1.3) are a class of enzymes that hydrolyze ester bonds in triacylglycerides to form fatty acids and glycerol (Jaeger \& Eggert, 2002). Lipases have recently emerged as key enzymes in swiftly growing biotechnology and are used in various industrial fields such as detergent, seasoning and food, pharmaceutical, ester derivatives of amino acids, industrial chemicals, biosensors, agrochemicals, biofuels, bioremediation, cosmetics, and perfumes (Hasan et al., 2006). In industrial processes, enzymatic reactions of lipase can be inhibited by several factors such as high salt concentrations, high or low $\mathrm{pH}$, organic solvents and high temperatures.

The stability and activities of enzymes produced by an organism tend to be suitable with the conditions of its natural habitat. Microorganisms

* To whom correspondence should be addressed. isolated from hot environments are an important source for the production of thermostable enzymes (Danson \& Hough, 1997). The researchers also saw the enormous potential of these thermophilic bacteria in the applications compared to ordinary bacteria because of the stability of enzymes produced by thermophilic bacteria was excellent during storage thereby reducing production costs.

Indonesia is potentially to have an abundant bacterial heterogeneity even though it is still poorly known. Results of the current study explains that in seafloor depth of over 10,000 meters, there is a diversity and abundance of living organisms in particular on seafloor ecosystems around hydrothermal vent volcanic activity. The research aimed to screen thermophilic bacteria from hydrothermal vent Kawio that potentially has thermostable lipase gene and its identification based on more reliable identification systems of $16 \mathrm{~S}$ rRNA analysis to proceed for further confirmation of its identity. 


\section{MATERIALS AND METHODS}

\section{Strain, plasmids, and culture medium}

All three bacteria (DS1, DS3, and DS4) used in this study were obtained from Biosciences and Biotechnology Research Center and previously derived from samples of hydrothermal vent seawaters near the volcano Kawio, North Sulawesi (Restiawaty et al., 2013). The sample used was taken in quantity of as much as 15 liters of hot springs hydrothermal vent area and has a temperature ranges from $35-80^{\circ} \mathrm{C}, \mathrm{pH} 2.8-3.0$, the level of salinity 35-40 ppt, and light conditions aphotic. The E. coli DH5 $\alpha$ that used for gene cloning was cultivated in Luria-Bertani medium at $37^{\circ} \mathrm{C}$ and the plasmid pJET1.2/blunt was used for cloning and sequencing of the lipase gene.

\section{Identification of bacteria}

Screening of thermophilic bacteria producing lipase is based on the ability of bacteria to produce lipase in the medium containing $1 \%$ tryptone, $0,5 \%$ yeast extract, $1 \% \mathrm{NaCl}, 2 \%$ agar, $2,5 \%$ olive oil, $1 \%$ Tween 80 , and $0,001 \%$ rhodamine $\mathrm{B}$. Isolates were incubated in an incubator at $37^{\circ} \mathrm{C}$ for 2 days and then transferred in an incubator at $50^{\circ} \mathrm{C}$ for 2 days. Positive lipase-producers were distinguished by the presence of orange fluorescent halos surrounding the colonies present on the plates observed under UV irradiation with a wavelength of $350 \mathrm{~nm}$ (Kouker \& Jaeger, 1987).

16S rRNA gene amplification using PCR process was carried out using a pair of universal primer, forward primer Bact27F (5'-AGA GTT TGG TGA TCM CTC AG-3') and reverse primer 1492R (5'- TAC STT GGT GTT ACG ACT T-3') (Lane, 1991). The PCR conditions were as follows: initial denaturation $\left(94^{\circ} \mathrm{C}, 5 \mathrm{~min}\right), 25$ cycles of denaturation $\left(94^{\circ} \mathrm{C}, 30 \mathrm{sec}\right)$, annealing $\left(45^{\circ} \mathrm{C}, 30 \mathrm{sec}\right)$, extension $\left(72^{\circ} \mathrm{C}, 1,5 \mathrm{~min}\right)$ and a final extension for $5 \mathrm{~min}$ at $72^{\circ} \mathrm{C}$. Product was run on $1 \%$ agarose gel electrophoresis and recovered using gel purification kit.

\section{Isolation and cloning of the lipase gene}

Lipase coding sequences from different $B$. pumilus strains were aligned and a set of primers was designed for the amplification of the lipase coding DNA from sample with incorporated restriction enzymes BamHI and NdeI. The sequence of the forward primer FLip1 was 5'-GCG CCA TAT GAA GAT AGT GAT TAA KYK HKT G -3' and that of the reverse primer RLip1 was 5'-GGA TCC TTA ATT CGT ATT YTG KCC TCC -3'. PCR was performed with an initial denaturation $\left(94^{\circ} \mathrm{C}, 4 \mathrm{~min}\right)$, followed by 35 cycles of denaturation $\left(94^{\circ} \mathrm{C}, 1 \mathrm{~min}\right)$, annealing $\left(60^{\circ} \mathrm{C}, 30 \mathrm{sec}\right)$, extension $\left(72^{\circ} \mathrm{C}, 1 \mathrm{~min}\right)$, and final extension for $3 \mathrm{~min}$ at $72^{\circ} \mathrm{C}$. Expected
PCR product was 665 base pairs. PCR product was electrophoresed on 1\% agarose gel for detection and purified using gel purification kit.

The purified fragment was directly cloned with pJET1.2/blunt cloning vector and the ligated product was transformed into $E$. coli $\mathrm{DH} 5 \alpha$ competent cells using heat shock method (Sambrook \& Russell, 2001). The cells were cultivated on LB-agar medium containing ampicillin $100 \mu \mathrm{g} / \mathrm{mL}$. Positive transformants were selected and confirmed by colony PCR method.

\section{Sequence analysis}

Lipase gene sequences were analyzed both on DNA level and protein level. Sequence similarity searches were performed in the GenBank database. Computer analysis of the amino acid sequence were performed with software including BLAST, the Expert Protein Analysis System (ExPASy) proteomics (http:// web.expasy.org/), Interpro (https://www.ebi.ac.uk), Swiss Modelling (https://swissmodel.expasy.org) and SAS (http://www.ebi.ac.uk/).

\section{RESULTS AND DISCUSSION}

\section{Identification of bacteria}

Isolate DS1 was found to be positive as lipaseproducer, as indicated by the presence of orange fluorescent halos around the colonies, when the Rhodamine B-olive oil agar plates were observed under UV rays (Figure 1). Isolates not producing lipase, such as DS3 and DS4, accumulated rhodamine B i.e., formed pink colored colonies, but did not show orange fluorescence upon UV irradiation. The florescence observed was due to reaction between rhodamine $\mathrm{B}$ complex formation with fatty acids, the product of olive oil hydrolysis catalyzed by lipase (Hou \& Johnston, 1992).

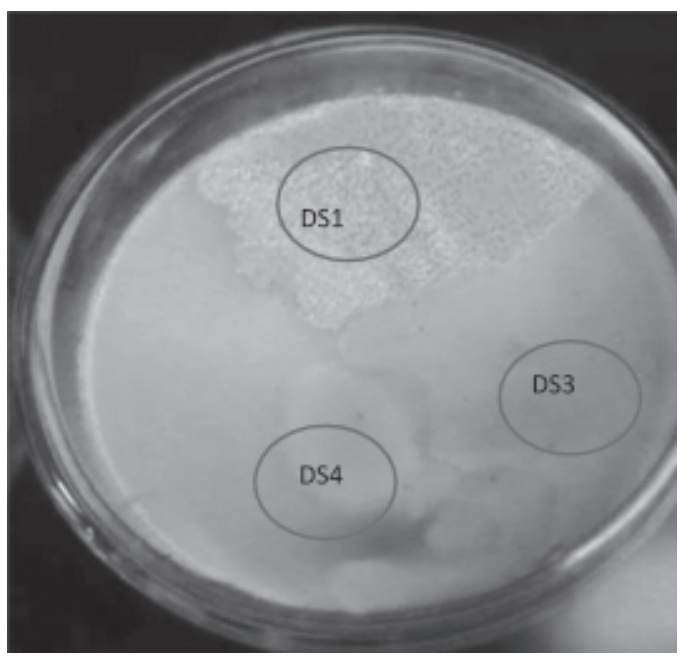

Fig. 1. DS1 Showed Positive Assay for Lipase Producing Isolate. 
In this study, the 16S rRNA gene sequence was found to represent a highly accurate and versatile method for identification of bacteria to the species level. Based on analysis of $16 \mathrm{~S}$ rRNA gene sequences, DS1 had the highest homology with Bacillus safensis strain FO-26b with significant value of $96,87 \%$ (Figure 2). This value of below $97 \%$ homology provided the possibility that the isolate used is a new species, which has not been identified in the GenBank database (Petti, 2007). Phylogenetic analysis showed that DS1 was clustered closely with genus Bacillus. Thus, DS1-01 was selected for further characterization.
The thermostable lipase gene was amplified from genomic DNA of DS1 by designing a pair of degenerating primers through alignment of sequences of different $B$. pumilus from database (Figure 3). The sequence of the putative lipase gene contained a complete ORF of length $648 \mathrm{bp}$ and was obtained by PCR from DS1 chromosome (Figure 4).

\section{Isolation and cloning of the lipase gene}

Lipase gene identification at protein level was carried out on DS1 lipase gene sequences that had been validated and deduced to the amino acid sequence. According to BLASTn analysis,

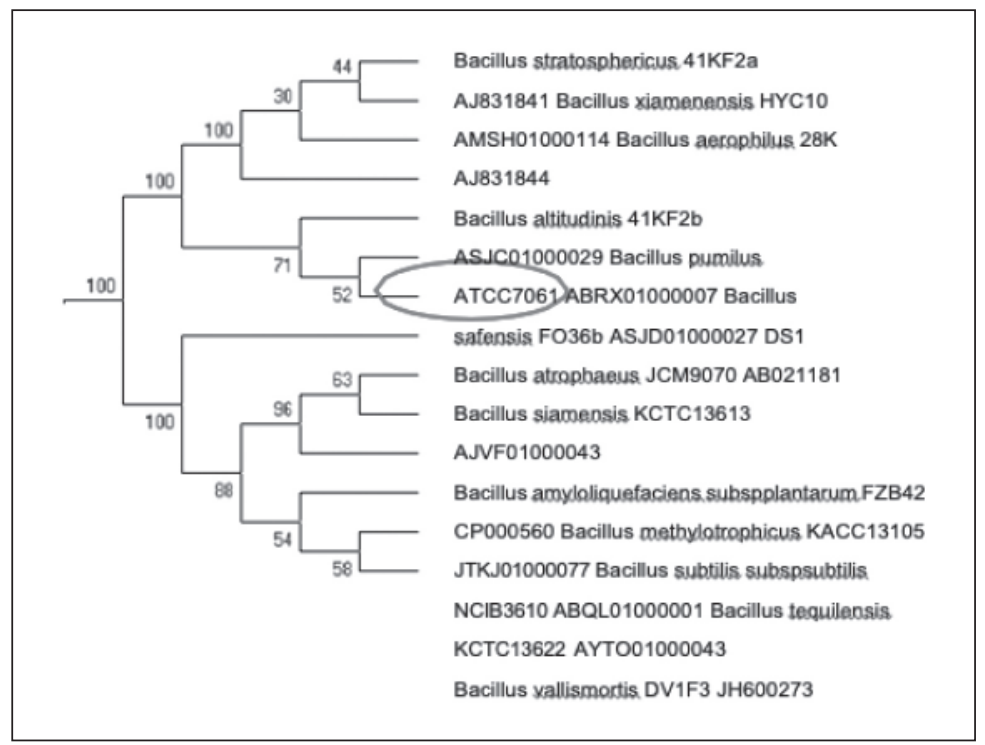

Fig. 2. Rooted Phylogenetic Tree Showing The Relationship of DS1 16S rRNA Gene.

\begin{tabular}{|c|c|c|c|}
\hline B. pumilus $\mathrm{PC} 1$ & $:-29$ & $5^{\prime}$ - ATGAAAGTGATGTTCGTTAAG - 3' & -49 \\
\hline B. pumilus YZ02 & $:-32$ & 5' - ATGAAAGTGATGTTTGTTAAG - 3' & -52 \\
\hline B. pumilus SW41 & $:-1$ & $5^{\prime}$ - ATGAAAGTGATTCGATTTAAG - 3' & -21 \\
\hline B. pumilus L5 & $:-1$ & 5' - ATGAAAGTGATGTTTGTTAAG - 3' & -21 \\
\hline B. pumilus Nws1c & $:-1$ & $5^{\prime}$ - ATGAAAGTGATTCGATTTAAG - 3' & -21 \\
\hline B. pumilus ArcL & $:-1$ & $5^{\prime}$ - ATGAAAGTGATTTGTTTTAAG - 3' & -21 \\
\hline Consensus & $:$ & $5^{\prime}$ - ATGAAAGTGATKYKHKTTAAG - 3' & \\
\hline FLip1 & & 5' - GCGCCA TATGATGAAAGTGATKYKH & KTTAAG -3 \\
\hline B. pumilus $\mathrm{PC} 1$ & $:-660$ & 5' - GGAGGACAGAATACGAATTAA - 3' & -680 \\
\hline B. pumilus YZ02 & $:-660$ & $5^{\prime}$ - GGAGGACAGAATACGAATTAA - 3' & -680 \\
\hline B. pumilus SW41 & $:-660$ & 5' - GGAGGACAGAATACGAATTAA - 3' & -680 \\
\hline B. pumilus L5 & $:-660$ & $5^{\prime}$ - GGAGGCCAGAATACGAATTAA - 3' & -680 \\
\hline B. pumilus Nws1c & $:-660$ & 5' - GGAGGACAGAATACGAATTAA - 3' & -680 \\
\hline B. pumilus ArcL & $:-660$ & 5' - GGAGGACAAAATACGAATTAA - 3' & -680 \\
\hline Consensus & $:$ & \multicolumn{2}{|l|}{ 3' - CCTCCKGTYTTATGCTTAATT - 5' } \\
\hline RLip1 & $:$ & \multicolumn{2}{|l|}{ 5' - CCTCCKGTYTTATGCTTAATTCCTAG G-3' } \\
\hline & & \multicolumn{2}{|l|}{$\mathbf{K}=\mathrm{G} / \mathrm{T} ; \mathbf{Y}=\mathrm{C} / \mathrm{T} ; \mathbf{H}=\mathrm{A} / \mathrm{C} / \mathrm{T}$} \\
\hline
\end{tabular}

Fig. 3. Sequences Alignment of Different B. pumilus Lipases from Database through CLUSTALW Multiple Sequence Alignment. 


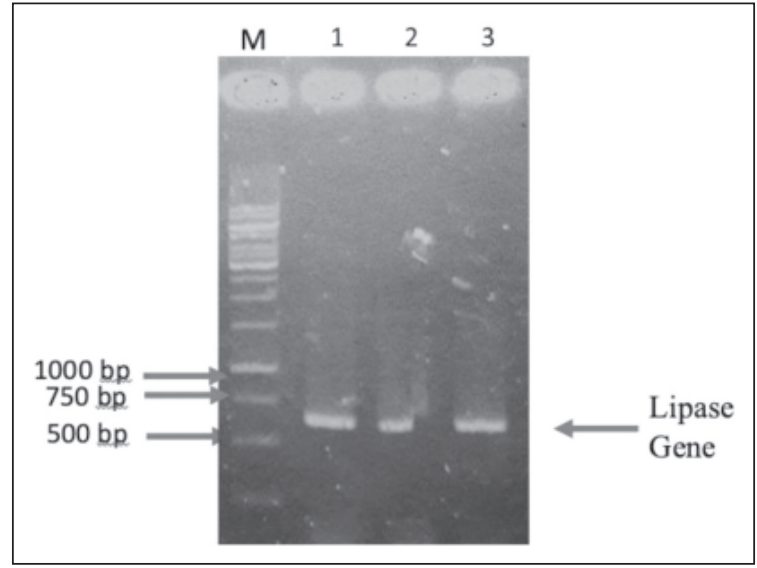

Fig. 4. The Electrophoresis Results of Lipase Gene Amplification ( $\mathrm{M}=$ DNA marker; 1,2,3 = repetition).

nucleotide sequence of DS1 lipase gene was $96 \%$, $91 \%, 87 \%, 87 \%$ and $73 \%$ identical to the lipase sequence from $B$. pumilus strain B106, B. licheniformis, Bacillus sp. strain B26, B. stratophericus, and B. subtilis HJ0-6, respectively. Complete lipase gene from DS1 has been isolated, shown by the presence of the start codon (ATG), stop codon (TAA) and the absence of early-termination codon in the sequence of genes. The translated DS1 lipase gene consisted of 215 amino acid residues and had the highest homology with lipase gene from Bacillus pumilus strain B106 (EU482152) with 98\% identity (Table 1).

\section{Sequence analysis of the lipase}

Phylogenetic analysis revealed that the lipase from DS1 and lipase from Bacillus pumilus and Bacillus subtilis were clustered in the same subgroup I.4 owing to their high degree of sequence identity. This is also supported by the analysis of putative molecular weight of DS1 lipase enzyme that is approximately $22,98 \mathrm{kDa}$. Modeling results showed the amino acid sequence of the DS1 lipase has similarity of $80.11 \%$ with a crystal structure of Bacillus subtilis lipase (Access Number: 1i6w.1) (Figure 5). Identification was also based on the analysis of protein structure annotation of DS1 lipase. Secondary structure of the DS1 lipase showed residues, which serve as the active site, binding of the ligand/cofactors and catalytic side (Figure 6). The putative signal peptide cleavage site of DS1 lipase was found to be located between Val-3 and Ala-25. Thus, the predicted catalytic site of DS1 recombinant lipase comprises the triad of Ser-111, Asp-167, and His-190. It possesses the conservative motif Ala-X-Ser-X-Gly, which is also found in $B$. pumilis and B. subtilis lipases, instead of the motif Gly-X-Ser-X-Gly found in common lipase (Misset et al., 1994). The deduced amino acid sequence was multiply aligned with 21 Bacillus lipase sequences obtained from GenBank, and exhibited a high degree of sequence similarity at the predicted active site regions (Ala-His-Ser-Met-Gly). These results suggested that we had indeed cloned a lipase gene from DS1 and that it belongs to subfamily I.4 of lipolytic enzymes.

Table 1. Similarity Percentage of Nucleotide and Amino Acid Sequences of Lipase gene

\begin{tabular}{lccccc}
\hline LipDS1 & LipPum & LipLich & LipBac & LipStrato & LipSub \\
\hline Nucleotide Sequence & $96 \%$ & $91 \%$ & $87 \%$ & $87 \%$ & $73 \%$ \\
Amino Acid Sequence & $98 \%$ & $92 \%$ & $90 \%$ & $91 \%$ & $83 \%$ \\
\hline
\end{tabular}

LipDS1: lipase Isolat DS1; LipPum: lipase B. pumilus strain B106 (EU482152); LipLich: lipase B. Licheniformis (AJ297356); LipBac: lipase Bacillus sp. strain B26 (AF232707); LipStrato: lipase B. stratosphericus strain L1 (KP331444); LipSub: lipase B. subtilis HJO-6 (CPO16894).

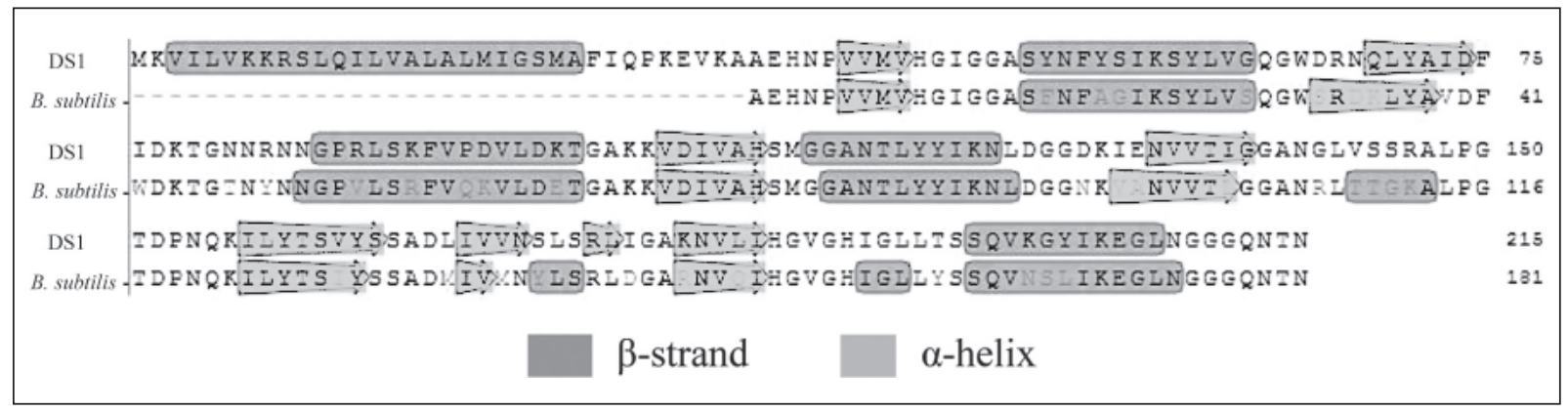

Fig. 5. Results of Amino Acid Sequence Alignment Lipase gene Isolates DS1 with B. subtilis using Swiss Modelling. 


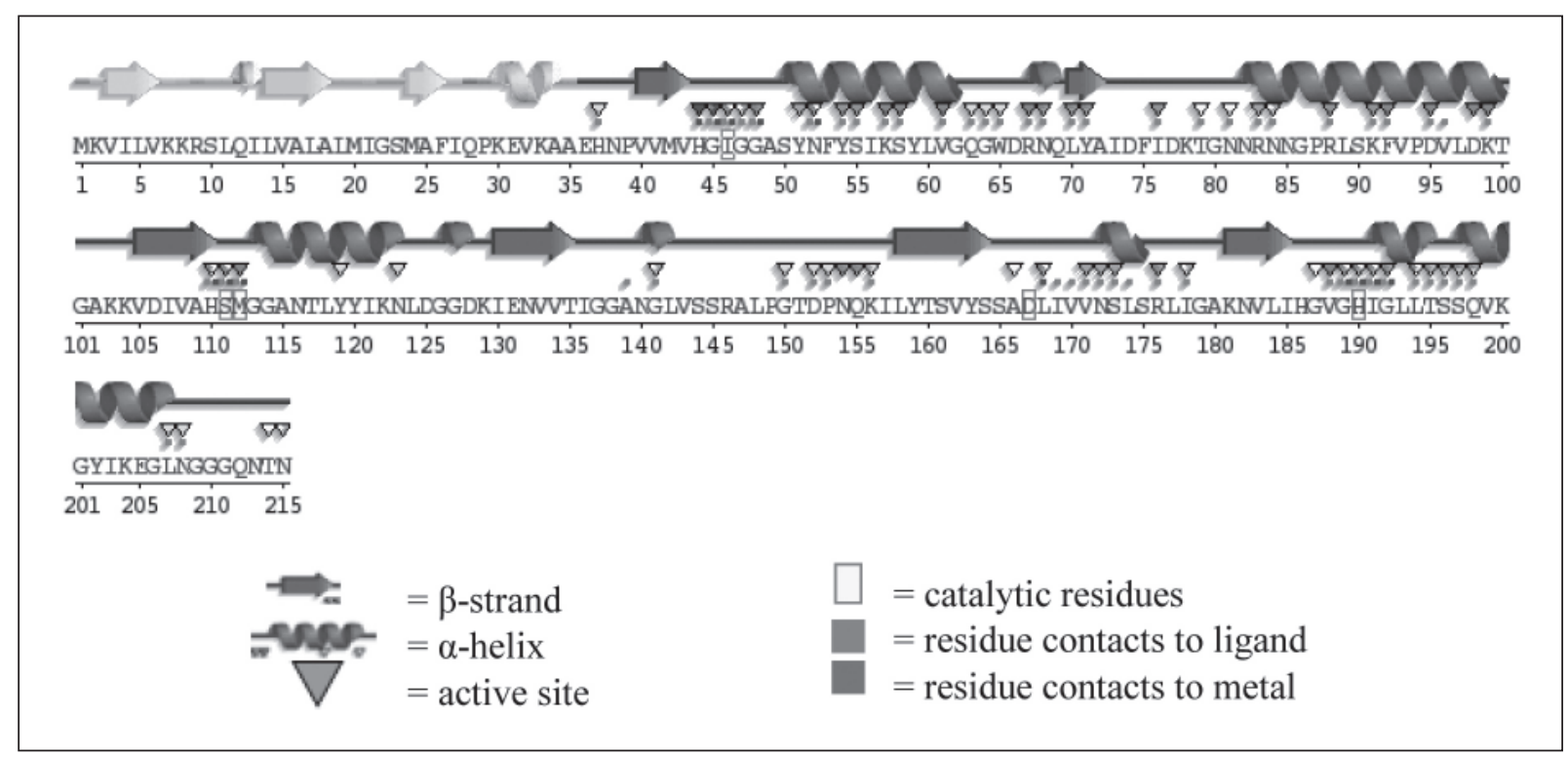

Fig. 6. Results of the Secondary Structure Analysis Lipase DS1 Using SAS.

\section{ACKNOWLEDGMENT}

The authors would like to thank Institute of Technology Bandung for supporting this research.

\section{REFERENCES}

Danson, M.J. \& Hough, D.W. 1997. The structural basis of protein halophilicity. Comparative Biochemistry and Physiology Part A: Physiology, 117(3): 307-312.

Hasan, F., Shah, A.A. \& Hameed, Abdul. 2006. Industrial applications of microbial lipases. Enzyme Microbial Technology, 39: 235-251.

Hou, C.T. \& Johnston, T.M. 1992. Screening of Lipase Activities with Cultures from the Agricultural Research Services Culture collection. Journal of American Oil Chemistry Society, 69: 1088-1097.

Jaeger, K. \& Eggert, T. 2002. Lipases for Biotechnology. 17-19 pp.

Kouker, G. \& Jaeger, K. 1987. Specific and Sensitive Plate Assay for Bacterial Lipases. Applied and Environmental Microbiology, 53(1): 211-213.
Lane, D.J. 1991. 16S/23S rRNA sequencing. Nucleic Acid Techniques in Bacterial Systematics (E. Stackebrandt \& M. Goodfellow, eds). New York, USA: Wiley, pp 115-175.

Misset, O., Gerritse, G., Jaeger, K., Winkler, U., Colson, C., Schanck, K., Lesuisse, E., Dartois, V., Blaauw, M., Ransac, S. \& Dijkstra, B.W. 1994. The structure-function relationship of the lipases from Pseudomonas aeruginosa and Bacillus subtilis. Protein Engineering, 7(4): 523-529.

Petti, C.A. 2007. Detection and Identification of Microorganisms by Gene Amplification and Sequencing. Medical Microbiology, 44: 11081114.

Restiawaty, E., Pertiwi, W.I., Aryantha, I.N.P. \& Natalia, D. 2013. Screening Bakteri untuk Biokonversi Limbah Biodiesel dari Diversitas Bakteri Indonesia. A poster in Seminar dan Pameran Inovasi dan Kontribusui Perempuan Peneliti ITB bagi Industri dan Masyarakat, 20 Desember, ITB, Bandung, Indonesia.

Sambrook, J.F. \& Russell, D.W. 2001. Molecular Cloning: A Laboratory Manual. 3rd Ed. Cold Spring Harbor Laboratory Press. 
